\title{
Pulmonary Complications in Measles 2016-2018
}

\author{
NARCISA DANIELA NICOLESCU1,2, VIRGIL FILARET MUSTA ${ }^{1,2}$, RUXANDRA LAZA ${ }^{1,2}$, ADELINA RALUCA MARINESCU1,2, \\ ANDREEA MIHAELA BIRLAD2*, VOICHITA LAZUREANU ${ }^{1,2}$ \\ ${ }^{1}$ Victor Babes University of Medicine and Pharmacy Timisoara, 2 Eftimie Murgu Sq., 300041, Timisoara, Romania \\ 2 Victor Babes Clinical Hospital of Infectious Diseases and Pneumophtisiology Timisoara, 13 Gheorghe Adam Str., 300310, \\ Timisoara, Romania
}

\begin{abstract}
Measles is a viral disease that we have chosen to talk about because of the progressively increasing number of cases, the respiratory complications that progress toward respiratory failure in children and because of the costs that could be lowerd if vaccinations were carried out according to the proposed Schedule by the Ministry of Health. Our research was conducted during 05.2016-31.12.2018 analyzed according to several criteria (age group, sex, personal history, complications, evolution, treatment, etc.). There are 3 particular clinical cases. From the pathophysiological point of view, we consider the focus on respiratory complications to be useful, most complications being alveolar pneumonia in children under 2 years of age, reaching to acute respiratory failure. Can we prevent this?
\end{abstract}

Keywords: Measles, vaccination, respiratory complications, children

Measles is still a problem in contemporary infectious pathology due to the possibility of severe forms of illness and / or complications in certain categories of patients. Lack of vaccination for multiple reasons is an element of disease emergence in the receptive population and in the evolution of cases in outbreaks or small epidemics that do not repeat the seasonality, even reaching epidemic outbreaks (ex: Measles in 2016-2018).

Out of over 10,500 cases of Measles in Romania 20162017, 38 deaths were recorded, of which 17 were in children under the age of 1 (not eligible for vaccination).

\section{Experimental part}

Material and methods

-Analysis of the measles incidence in Timis County in recent years;

-data on the distribution of cases in the other counties in

Romania;

-comparison with measles mortality from past decades;

-presenting the number of cases of measles from other countries in Europe and America;

-analysis of severe forms and complications (especially pulmonary) in measles, respectively causes of death;

-presentation of particular cases of measles.

Anti-measles vaccination has been introduced in Romania from 1960, which has definitely contributed to a decrease in morbidity. Since 1972, we have been using MMR vaccines.

In 1993, in the Victor Babes Hospital of Infectious Diseases in Timisoara there was a peak epidemic of measles and there were respiratory and neurological complications (encephalitis), the virus being definitely neurotropic. That year many deaths were recorded.

In 2004-2005 219 cases of measles (especially children) were hospitalized at IInd Clinic of Infectious Diseases at Victor Babes Hospital in Timi-oara, the complications being respiratory and neurological, but with low lethality $(0.91 \%)$.

In 2011, 272 cases of measles were hospitalized in IInd Clinic of Infectious Diseases at Victor Babe- Hospital in Timi-oara, and in 2012, 231 cases of measles were hospitalized (fig. 1).

It is important to underline several aspects:

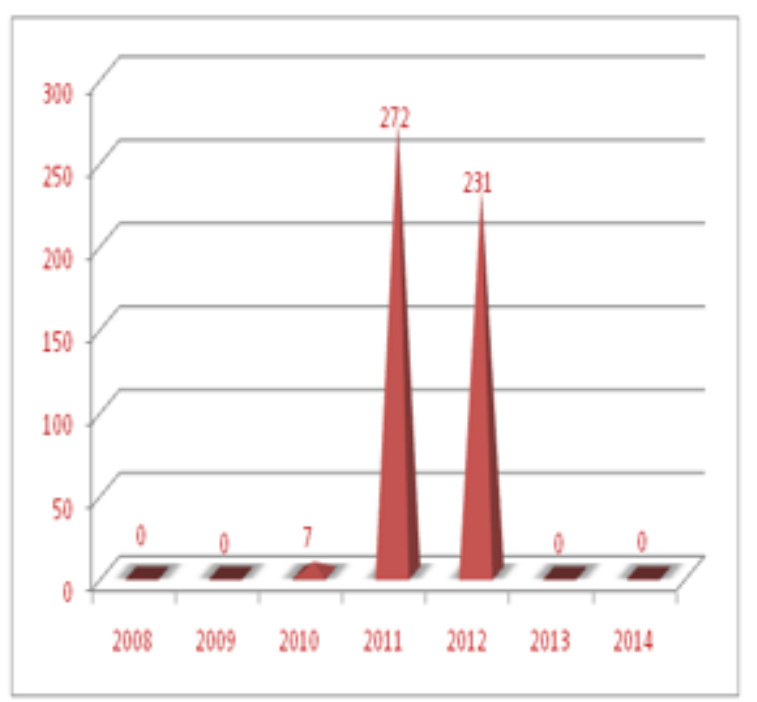

Fig.1. Distribution of measles cases per year in IInd Clinic of Infectious Diseases at Victor Babes Hospital in Timisoara

- In the years 2013 and 2014 no cases of measles were hospitalized at IInd Clinic of Infectious Diseases at Victor Babes Hospital in Timisoara.

- In 2014, 644 cases were reported in the USA in 27 states (the highest number of cases in the last 25 years).

- in Europe, there were 41,000 cases in 2018 in the first 6 months, with most cases $(23,000)$ in Ukraine, then Serbia, Russia, Italy, Georgia, Greece, Romania. 23927 in 2017 and 5273 in 2016 (figs. 2-4).

In the period 2016-2017 there were 10500 cases in Romania with 38 deaths.

In the period 2016-2018 there were 14825 cases with 58 deaths.

The first cases in Timis County appeared in April 2016 with a subsequent gradual increase.

Initially cases appeared in some counties, then extended to other counties: Timis, Arad, Caras Severin, etc., to mention that IInd Clinic of Infectious Diseases at Victor Babes Hospital from Timisoara took over many cases of severe measles and also cases from counties as Arad, Caras Severin, Hunedoara, Mehedinti. 


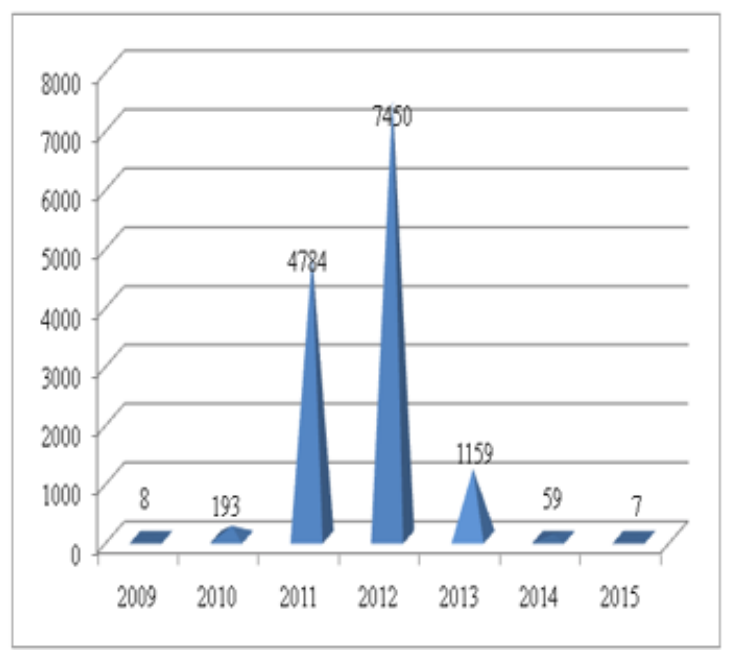

Fig. 2. Distribution per years of measles cases in Romania

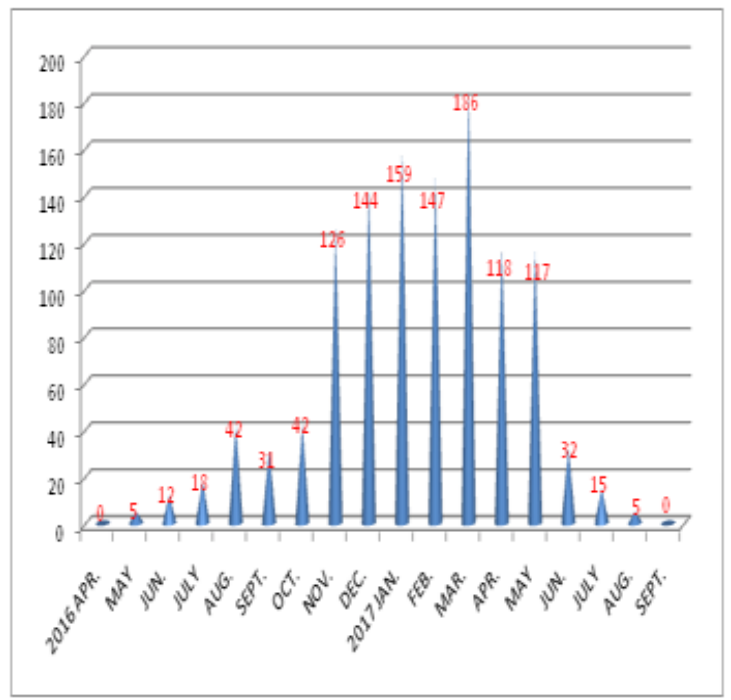

Fig. 3. Distribution per month of cases of measles in the period 2016-2017 in the IInd Clinic of Infectious Diseases at Victor Babes Hospital in Timisoara

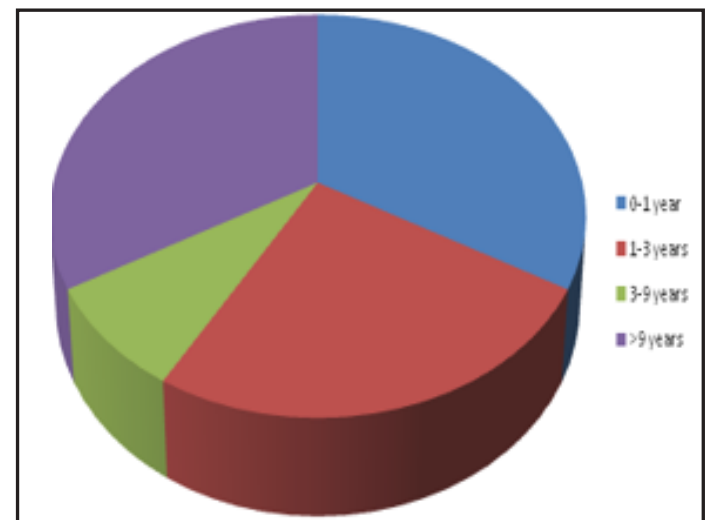

Fig. 4. Distribution by age group of deaths at IInd Clinic of Infectious Diseases at Victor Babe- Hospital in Timisoara

The last case of measles in Timis was in September 2017, with the remark that other cases may occur due to the accumulation of a receptive population and the highly contagious virus.

Later cases of measles were reported from other counties in Romania, which were not initially affected, namely Braila, Galati, Tulcea.

In the current epidemic there have been many respiratory complications (notneurological-unlike previous years-1993,2004 and 2005).

These respiratory complications were mostly in the small age group (0-2 years), patients not able to be vaccinated in some cases, with inconsistency between functional respiratory syndrome and radiological appearance. There have been several complications of alveolar pneumonia with acute respiratory failure sometimes rapidly installed and refractory to treatment.

Most children, especially infants who developed respiratory failure as a complication, had a history of repeated episodes of emphysematous bronchiolitis resistant to treatment and had a rapid evolution towards exitus despite the complex treatmentset up in the intensive care unit.

These aspects have led us to take into account, in some cases, the interstitial lung disease entity CH-ILD. These diseases have been mentioned in recent years in the literature of Romania and other countries, with three etiologies (known cause, systemic diseases, unknown cause). Histologically alveolar structures are altered, the prevalence being variable. There are many ILD syndromes identified exclusively under different names in infants.

We present some particular cases of measles with alveolar pneumonia and refractory respiratory insufficiency at treatment.

\section{CASE 1}

P.K, 1 year and 3 months, female, rural environment, admission period: 11.12.2016-18.12.2016

Diagnosis: Acute Respiratory Distress with Respiratory Insufficiency, Mixed Pneumonia, Suspicion of measles, Cardio-respiratory arrest, Esophageal type III atresia, Esophageal residual stenosis, Laryngeal Stridor, Acute dehydration syndrome, Acute stomatitis, Acute enterocolitis, Hyponatremia, Hyperimmunoglobulinemia $\mathrm{E}$, Post-sepsis status with pulmonary point of departure, mild motor-motion retard, atopic terrain.

Patient with multiple pathological personal history: Esophageal type III atresia, residual esophageal stenosis, laryngeal stridor, repeated bronchiolitis and pneumonia, had fever, rhinorrhea, loss of appetite, dry cough and since day 1 maculo-papular rash on the face.

At the time of admission to our Clinic, the objective exam was: general influenced state, saburral tongue, face with maculo-papular rash, bilateral latero-cervical micropoliadenopathy, bronchial and subcrepitant rales bilateral, more pronounced on the right, laryngeal stridor and accelerated intestinal transit with low consistency stools.

Biological Investigations (table 1).

Table 1

BIOLOGICAL INVESTIGATIONS CASE 1

\begin{tabular}{|l|l|}
\hline & $\mathbf{1 2 . 1 2 . 2 0 1 6}$ \\
\hline Leukocytes & $10330 / \mu \mathrm{Ll}$ \\
\hline RBC & $4600000 / \mu 1$ \\
\hline Haemoglobin & $11,5 \mathrm{~g} / \mathrm{dl}$ \\
\hline Haematocrit & $35 \%$ \\
\hline Trombocites & $332000 / \mu 1$ \\
\hline Leucocytes & $\mathrm{NE}=68,3 \%$, \\
formula & $\mathrm{LY}=21,7 \%$, \\
& $\mathrm{MO}=9,7 \%$, \\
& $\mathrm{EO}=0,1 \%, \mathrm{BA}=0,2 \%$ \\
\hline ESR & $55 \mathrm{~mm} / \mathrm{h}$ \\
\hline CRP & $28,16 \mathrm{mg} / 1$ \\
\hline TGO & $38,9 \mathrm{mg} / \mathrm{dl}$ \\
\hline TGP & $23,1 \mathrm{mg} / \mathrm{dl}$ \\
\hline Glucose & $46 \mathrm{mg} / \mathrm{dl}$ \\
\hline Creatinine & $0,22 \mathrm{mg} / \mathrm{dl}$ \\
\hline Urea & $18,2 \mathrm{mg} / \mathrm{dl}$ \\
\hline
\end{tabular}


- Posteroanterior thorax radiography: Homogeneous condensation right subscizural, apparently alveolar type. Associated bilateral changes peribronchial and perihilar. No pleural collections.

- Antibiotic therapy (Ceftriaxone 12.12.-18.12.2016, Gentamicin 12.12.-18.12.2016, Bactrim 15.12-18.12.2016), Corticosteroids (HHS), Hydroelectrolytic and caloric rebalancing solutions, Peristaltic Reglator (Debridat), H2 Receptor Blocker (Arnetin), Antitermics (Algocalmin, Paracetamol), Anti-inflammatory (Algin), Expectorantand Mucolytic (Koflet), Bronchodilatator(Ventolin), Probiotics, Oxygenotherapy.

- Parenteral therapy was administered on the central venous catheter.

During hospitalization, the condition of the patient remained influenced, becoming severe with respiratory failure with $\mathrm{SaO} 2=76 \%$ with 02 on the mask. On the seventh day of admission, it shows a state of agitation with $\mathrm{SaO} 2=65 \%$, then cardio-respiratory arrest. Resuscitation maneuvers were initiated, orotracheal intubation, adrenaline and dopamine were administered, but without therapeutic response. The death was declared.

Necropsy: Diagnosis: Softness of the brain. At the autopsy from a piece of lung, PCR tested $=>$ Measles confirmation.

\section{CASE 2}

N.A, 8 months, male, urban environment, admission period: 16.12.2016-09.01.2017

Diagnosis: Respiratory distress syndrome with mechanical prothesis (intubation), Cardiac arrest, Spontaneous pneumothorax, Pseudomonas aeruginosa infection, Mixed anemia, Gastroesophageal reflux, Post perinatal HIE status.
A child with multiple pathological personal history for which he was admitted to the Louis Turcanu Hospital, II Pediatric Clinic (Mixed Pneumonia, Acute Respiratory Impairment/Insufficiency, Gastro-esophageal Reflux, Anemia, Acute Vomiting Syndrome). He is transferred to our Clinic for the 4 days long fever associated with maculopapular rash.

Upon admission to our Clinic, the objective exam showed: general influenced condition, subfebrile child, low appetite, oculo-nasal catarrh, maculo-papular rush on the face, neck and chest, Positive Koplik sign, congestive pharyngeal with posterior secretions, micropoliadenopathy laterocervical bilateral, bilateral disseminated rhonchus, psychomotor agitation.

Biological Investigations (Table 2).

-Measles titre serology $=0.94$ (Equivocal).

-Repeated Chest X-rays were performed:

-21.12.2016: Pneumonic condensation process like pneumoniae with right upper lung lobe projection.

-23.12.2016: Oro-tracheal intubation tube. Expanded condensation processes that interested quasi-completely the left lung and right upper lung lobe, compared to previous radiography.

-27.12.2016: Expanded condensation points with quasicomplete right pulmonary interest and $1 / 2$ upper left lungin extenso: In observation for right pleurisy. OTI tube.

-30.12.2016: Pneumonic condensation processes in the right lung and $2 / 3$ lower left pulmonary lobe. Stationary IOT tube.

-03.01.2017: Bilateral pneumonic type condensation processes, slightly reduced in intensity compared to previous radiographs.

Table 2

BIOLOGICAL INVESTIGATIONS- IN EVOLUTION CASE 2

\begin{tabular}{|c|c|c|c|c|c|c|c|c|c|c|c|}
\hline & 19.12 .2016 & 22.12 .2016 & 23.12 .2016 & 26.12 .2016 & 27.12 .2016 & 29.12 .2016 & 30.122016 & 31.122016 & 03.01 .2017 & 05.01 .2017 & 09.01 .2017 \\
\hline IWBC & 10650 & 9250 & 11390 & 12030 & 14100 & & 15980 & & 11140 & 12050 & 13640 \\
\hline RBC & 5040000 & 4670000 & 4750000 & 4370000 & 3940000 & & 3290000 & & 4130000 & 3920000 & 3580000 \\
\hline Haemoglabia & 9,2 & 8,5 & 10,2 & 9,4 & 8,4 & & 7 & & 9,7 & 9,3 & 8,9 \\
\hline Haematocrit. & 29,3 & 27,6 & 32 & 29,3 & 26,3 & & 22,9 & & 31,6 & 31,5 & 31,6 \\
\hline Trommbociter & 472000 & 374000 & 494000 & 716000 & 777000 & & 1019000 & & 886000 & 562000 & 230000 \\
\hline $\begin{array}{l}\text { Leucocytes } \\
\text { formula }\end{array}$ & $\begin{array}{l}\mathrm{N}-37, \mathrm{~L} \\
53,5 \mathrm{M} \text {. } \\
9,3, \mathrm{E}-0 \mathrm{~B} \\
0,2\end{array}$ & $\begin{array}{l}\text { N-48,L- } \\
37,1 \mathrm{M} \text {. } \\
14,8, \mathrm{E}- \\
0, \mathrm{~B}-0,1\end{array}$ & $\begin{array}{l}\mathrm{N}-63, \mathrm{~L}-25,5 \mathrm{M}- \\
11,3, \mathrm{E}-0,1, \mathrm{~B}-0,1\end{array}$ & $\begin{array}{l}\text { N-66,7,L- } \\
19,5 \mathrm{M} \text { - } \\
13,5, \mathrm{E}- \\
0,2, \mathrm{~B}-0,1\end{array}$ & $\begin{array}{l}\text { N-77,9,L- } \\
11,8 \mathrm{M}- \\
10,1, \mathrm{E}- \\
0,1, \mathrm{~B}-0,1\end{array}$ & & $\begin{array}{l}\mathrm{N-77,5,L} \\
16,7 \mathrm{M} \text { - } \\
11,2, \mathrm{E}- \\
0,5, \mathrm{~B}-0,1\end{array}$ & & $\begin{array}{l}\text { N-72,6,L- } \\
20,4 \mathrm{M} \text { - } \\
6,6, \mathrm{E}-0, \\
\mathrm{~B}-0,4\end{array}$ & $\begin{array}{l}\mathrm{N}-64,7, \mathrm{~L}- \\
23,6 \mathrm{M}- \\
11,5, \mathrm{E}-0, \\
\mathrm{~B}-0,2\end{array}$ & $\begin{array}{l}\text { N-57,8,L-34, } \\
\text { M-7,7, E-0,1, } \\
\text { B-0,4 }\end{array}$ \\
\hline GOT & 100,5 & 159,4 & 66,4 & 47,8 & 25,8 & & 109 & & 84,1 & 38,6 & 32,6 \\
\hline$\overline{\text { CPT }}$ & 82,2 & 57,6 & 35,6 & 22,4 & 18 & & 54,2 & & 112,7 & 53,7 & 18,8 \\
\hline Urea & 26,1 & 20,7 & 23 & 13,8 & 13,5 & & 16,9 & & 19,8 & 37,5 & 27,1 \\
\hline Uric acid & & 6,48 & & & & & & & & & \\
\hline Glucose & 72 & 98 & 119 & 96 & 116 & & 132 & & 91 & 214 & 99 \\
\hline Cresatinine. & 0,29 & 0,16 & 0,17 & 0,11 & 0,12 & & 0,18 & & 0,04 & 0,19 & 0,18 \\
\hline ESC & 5 & 15 & 10 & & 30 & & 20 & & 10 & 10 & 5 \\
\hline CRP & 0,62 & 40,32 & 62,03 & 5,06 & 2,04 & & 1,78 & & 8,35 & 0,95 & 22,61 \\
\hline $\begin{array}{l}\text { Coagulation } \\
\text { factors }\end{array}$ & & $\begin{array}{l}\text { PT- } \\
12,6, \mathrm{INR}- \\
1,19, \mathrm{~F}- \\
2,84\end{array}$ & $\begin{array}{l}\text { PT-13,7,INR- } \\
1,29, \mathrm{~F}-2,32\end{array}$ & $\begin{array}{l}\text { PT- } \\
12,8, \text { INR- } \\
1,21, \text { F- } \\
2,88\end{array}$ & $\begin{array}{l}\text { PT- } \\
13,1, \text { INR- } \\
1,24, F- \\
2,88\end{array}$ & & $\begin{array}{l}\text { PT- } \\
13,9, \mathrm{INR} \text { - } \\
1,31, \mathrm{~F}- \\
\mathbf{2 , 2 5}\end{array}$ & & $\begin{array}{l}\text { PT- } \\
13,4, \text { INR- } \\
1,26,5 \text { - } \\
3,84\end{array}$ & $\begin{array}{l}\text { PT- } \\
12, \mathrm{INR}- \\
1,13, \mathrm{~F} \text { - } \\
1,87\end{array}$ & $\begin{array}{l}\text { PT-14,5,INR- } \\
1,37,5-1,87\end{array}$ \\
\hline BT & & 0,09 & 0,13 & & 0,1 & & 0,14 & & 1,33 & 0,7 & 0,59 \\
\hline $\mathrm{BD}$ & & 0,01 & 0,06 & & 0,08 & & 0,07 & & 0,58 & 0,13 & 0,13 \\
\hline $\begin{array}{l}\text { Alkaline } \\
\text { phosphatase }\end{array}$ & & 146,5 & & & & & $\mathbf{5 5 7 8}$ & & & & \\
\hline Amxlasemie & & 65,4 & & & & & & & & & \\
\hline Rrocalcitonia & & 0,5 & 0,43 & & 0,19 & & & & & & \\
\hline Hemoculture & & ABSENT & & & & & & ABSENT & & & \\
\hline $\begin{array}{l}\text { Bronchial } \\
\text { aspirate }\end{array}$ & & & $\begin{array}{l}\text { Pseudomonas } \\
\text { aernginosa, } \\
\text { Candida }>10 \text { OCC }\end{array}$ & & & $\begin{array}{l}\text { Pseudomonas } \\
\text { aeruginosa }\end{array}$ & & & & & \\
\hline Cholinesterax & & & 3742 & 7033 & 6390 & & & & 5635 & 5413 & 5292 \\
\hline
\end{tabular}


-09.01.2017: Complete left pneumothorax, right alveolar condensation processes, partial right pneumothorax, extended right latero-cervical and OTI.

-Thoracic Surgery Consultation: Massive Left Pneumothorax. Left pleuroctomy is practiced, air is evacuated. Band Aid. Aspiration drainage is recommended. Surgical reassessment when needed.

-Treatment: Antibiotic therapy (Meronem + Vancomycin, then Colistin), Antifungal (Fluconazole), Hydroelectrolytic and caloric rebalancing solutions, Blood and blood derivatives, Gastric protectors, Corticosteroids, Opioid and Nonopioidal Antalgies, Antipyretics, , Prokinetics, vasopressors.

Patient status remained influenced, fever, palpebral edema, perioral cyanosis, decreased 02 saturation, polypnea and intercostal circulation. After 11 days after admission, the patient is transferred to the Intensive care compartment with $\mathrm{SaO} 2=65-77 \%$ with 02 per mask, intercostal circulation and perioral cyanosis. Oro-tracheal intubation was then performed and therapy supplemented, but the patient's condition continued to be severe for another 19 days when he had cardiac arrest by bradycardia. Despite resuscitation maneuvers and rescue therapy, the patient died.

At autopsy-PCR positive for Measles.

\section{CASE 3}

A.A.K., 11months, male, urban environment, admission period: 25.12.2016-09.01.2017.

Diagnosis: Measles with severe complicated form and acute respiratory failure, Acute alveolar pneumonia, Acute enterocolitis, Acute dehydration syndrome, Thrombocytosis.

The onset of the current disease starts 4 days before with fever, oculo-nasal catarrh and cough. On the third day of onset, maculo-papular rash occurs. On the 4 th day since the onset of the disease he was presented at the emergency service of Louis Turcanu Hospital, where, he was clinically and biologically investigated and received antipyretics, bronchodilators, hydro-electrolytic rehydration solutions, aerosols with adrenaline were administered, and later the patient was guided in our Clinic.

Upon admission to our Clinic, the objective exam was: bad condition, infantile, no fever, loss of appetite, maculopapular rash, facial cyanosis, crying facies, oculo-nasal catarrh, congested pharynx, positive Koplik sign, ronchuses and disseminated subcrepit rales bilateral, abdominal respiration, $\mathrm{SaO} 2=65 \%$ spontaneously and $78-90 \%$ with 02 on the mask, AV = 150bpm, dry skin, accelerated intestinal transit with low consistency stools.

Biological investigations (table 3).

Interdisciplinary consultation:

25.12.2016: Anaesthesia and intensive care consultation: At the time of the consultation of the patient with a general influenced state, spontaneous breathing 02 on facial mask $\mathrm{SaO} 2=92 \%$. Vesicular murmur bilaterally tightened, bilateral roncus rale. Haemodynamic: $\mathrm{BP}=90$ $160 \mathrm{mmHg}$, Pulse $=160 \mathrm{bpm}$, without vasopressor support. Soft abdomen, allows pal pation, intestinal transit present, diarrhea stools. Present diuresis. Afebrile. Recommendations: Further treatment, Monitoring of vital functions, diuresis, stools. In case of aggravation reconsider intensive care.

Postero-anterior thoracic radiography: Increased right hil, bilateral interstitial perihilaral and infrahilar increased tissue, normal heart.
Table 3

BIOLOGICAL INVESTIGATIONS-IN EVOLUTION CASE 3

\begin{tabular}{|l|l|l|l|}
\hline & 27.12 .2016 & 04.01 .2017 & 09.01 .2017 \\
\hline WBC & $16440 / \mu 1$ & $27200 / \mu 1$ & $8870 / \mu 1$ \\
\hline RBC & $4100000 /$ & $4660000 / \mu 1$ & $4050000 / \mu 1$ \\
& $\mu 1$ & & \\
\hline Haemoglobin & $9,7 \mathrm{~g} / \mathrm{dl}$ & $11,2 \mathrm{~g} / \mathrm{dl}$ & $9,8 \mathrm{~g} / \mathrm{dl}$ \\
\hline Haematocrit & $29,3 \%$ & $34,8 \%$ & $30,1 \%$ \\
\hline Trombocites & $358000 / \mu 1$ & $919000 / \mu 1$ & $334000 / \mu 1$ \\
\hline $\begin{array}{l}\text { Leucocytes } \\
\text { formula }\end{array}$ & $\begin{array}{l}\mathrm{NE}=36 \%, \\
\mathrm{LY}=36 \%, \\
\mathrm{MO}=28 \%,\end{array}$ & $\begin{array}{l}\mathrm{LY}=36 \%, \\
\mathrm{MO}=13,3 \%,\end{array}$ & $\begin{array}{l}\mathrm{NE}=16,7 \%, \\
\mathrm{LY}=65,4 \%, \\
\mathrm{EO}=16,5 \%,\end{array}$ \\
\hline ESR & $\mathrm{EO}=0 \%$, & $\mathrm{EO}=1,3 \%, 9 \%$, \\
\hline CRP & $\mathrm{BA}=0 \%$ & $\mathrm{BA}=0,2 \%$ & $\mathrm{BA}=0,5 \%$ \\
\hline TGO & $20,85 \mathrm{mg} / 1$ & $2,11 \mathrm{mg} / 1$ & $1,67 \mathrm{mg} / 1$ \\
\hline TGP & $83,7 \mathrm{U} / \mathrm{L}$ & $36,6 \mathrm{U} / \mathrm{L}$ & \\
\hline Glucose & $42,1 \mathrm{U} / \mathrm{L}$ & $30,4 \mathrm{U} / \mathrm{L}$ & \\
\hline Creatinine & $115 \mathrm{mg} / \mathrm{dl}$ & $75 \mathrm{mg} / \mathrm{dl}$ & \\
\hline Urea & $0,16 \mathrm{mg} / \mathrm{dl}$ & $0,19 \mathrm{mg} / \mathrm{dl}$ & \\
\hline Serum iron & $15,4 \mathrm{mg} / \mathrm{dl}$ & $41,2 \mathrm{mg} / \mathrm{dl}$ & \\
\hline LDH & $39,5 \mathrm{pg} / \mathrm{dl}$ & & $31,2 \mathrm{pg} / \mathrm{dl}$ \\
\hline Total protein & $839 \mathrm{U} / \mathrm{L}$ & & \\
\hline
\end{tabular}

29.12.2016: Postero-anterior thorax radiography: Pulmonary condensation with right upper lobe projection. Possible alveolar condensation at left lobe.

05.01.2017: Postero-anterior thorax radiography: Radiological remission of the left lobe condensation.

-Treatment: Antibiotic therapy (Meronem + Vancomycin25.12.2016-06.01.2017, then Ceftriaxone until 09.01.2017), Corticosteroids (HSH with gradual decrease in doses), Antipyretics (Algocalmin, Paracetamol), Hydroelectrolytic and caloric rebalancing solutions, Diuretics (Furosemide), Gastric protectors, Bronchodilators (Ventolin), Oxygen therapy.

The patient's progress was slowly favorable, and on the 16th day of the admission, the mother of the child requested the discharge, contrary to the medical opinion.

\section{Results and discussions}

Measles is an infectious disease that can be prevented by vaccination;

The verylarge number of cases in the period 2016-20172018 is explained by the decrease in the vaccination rate in the last years and the accumulation of a receptive population;

In the period of 2016-2017-2018 measles caused many respiratory complications, some with acute respiratory failure and even death;

Patients with cardiac, renal, digestive, neurological (paraplegia) malformations had unfavorable evolution. Also, those with a history of bronchiolitis have evolved with acute respiratory failure compared to other categories;

There have been cases of children with measles who have also developed pneumothorax. In other cases, softness of the brain (through complex mechanisms) was detected in the necropsy examination;

There are still many aspects to be analysed and researched on measles which is a disease with deeply transitory acquired immunodepression;

7 of the 11 deaths in our Clinic, respectively 63.33\%, were in the age group 0-2 years by respiratory complications; 
In our country the total number of deaths was 40 when we started this paper, but unfortunately the number has increased to 59 deaths, of which 33 in children;

We believe that complex studies are required on the factors involved in the occurrence of severe forms and complications of measles;

21 cases of measles were reported in week 0516.12.2018 from Bucharest, Teleorman, Bacau, Salaj, Buzau, Galati, Vaslui.

\section{Conclusions}

It has been shown that in the current epidemic, the measles virus had respiratory tropism.

There have been many deaths, especially in the age group of 0-2 years; Certainly there have been many factors involved in the occurrence of severe and / or complicated forms - various cardiac and cerebral malformations, but also a history of bronchiolitis refractory to treatment or other respiratory conditions.

A hypothesis we have formulated, butfor which we need many studies and complex investigations to confirm, would be possible respiratory system immunity deficits (besides the well-known fact that in infants and young children the immunity is lower, also in those who are not naturally supplied) - mention case 2 with Measles and Respiratory distress syndrome - (death) -> in 2018 one sister aged 1 month experienced severe pulmonary disease with acute respiratory failure requiring mechanical ventilation .

In our database, some atypical complications have been encountered in infants and young children - respectively pneumothorax, softness of the brain, etc.

It should be mentioned that the total number of cases of measles in Romania was 15587 on 21 December 2018, but the measles epidemic continues in early 2019, with other cases reported in many counties.

21 cases of measles were reported in week 0516.12.2018 from Bucharest, Teleorman, Bacau, Salaj, Buzau, Galati, Vaslui.

\section{References}

1. *** European Centers for Disease Control and Prevention (ECDC), https://ecdc.europa.eu/en/news-events/epidemiological-updatemeasles-monitoring-european-outbreaks-12-may-2017;

2. NICOLESCU N., CRISAN A., NICOARA E., LAZUREANU V., LAZA R., MUSTA V., MARINESCU A. Antimeasles vaccination - pro and against, Medicine in Evolution- vol XXI, nr 2, 2015, p. 24;

3.LONG S.S., PROBER C.G., FISHER M. Principles and practice of Pediatric Infectious Diseases, -fifth edition, 2018, p. 62-64, 195, 234, 238;

4. DRAGOMIR D.- CH-ILD- Children interstitial lung diseases, Romanian J ournal of Pediatrics, vol LVI, nr.4 2007, p. 313-319;

5. NICOLESCU N., CRISAN A., NICOARA E., LAZUREANU V., LAZA R., MUSTA V., MARINESCU A., BIRLAD A.-Clinical evolutional aspects in present day measles, BMC infectious disease 2016, nr 16, supl. 4(A68) p. 56-57;

6. NICOLESCU N., CRISAN A., NICOARA E., LAZA R., MUSTA V., OANA M.-Current clinical and therapeutic issues in measles, BMC infectious diseases 2013, nr 13, supl 1, p106;

7. APOSTOLESCU C., ATAMAM T., AZOICAI D., BALTEANU M.A, BANCESU A., BUZOIANU E., CALITRU P.I., CARUNTU F. A., CARSTINA D., CINTEZA M.,-Tratat de Boli infectioase sub redactia Emanoil Ceausu, Editura medicala, Vol 1, Bucuresti, 2018, p. 610-617, 660-668; 8. STANESCU D., MOISIL T., NICOLESCU N., NICOARA E., MUSTA V., LAZUREANU V., MARTINCU R.-Rujeola- o infecie emergenta, Simpozion Naional de Patologie infecioasã 19-21 mai 2005, Gura Humorului, Volum de rezumate, pg 79-80;

9. GHEORGHE A.S., POPA M.I.,- Rolul cadrelor medicale in cresterea aderentei la programul de imunizare - InfectioRO, nr 41(1/2015), p. 912 ;

10. NICOARA E., LAZUREANU V., MUSTA V., NICOLESCU N., OANCEA C., LAZA R., DESAGA D.- Curs de Boli infectioase, Ed. de Vest Timisoara, 2015, p. 42-46;

11. CRISAN A., NICOARA N.-Boli infectioase in imagini- Ed. Excelsior Art, 2009, p. 125-132.

Manuscript received: 15.08 .2019 